\title{
POEMAS
}

\section{Bibiana Bernal}

\section{RAYUELA}

Nadie transita esta calle.

Apenas yo, tratando de ir conmigo,

bajo una lluvia finísima que aún no alcanza

a alumbrar el asfalto.

Cruzo la cebra

como quien juega a la rayuela

y se equivoca,

sin buscar ningún cielo.

\section{Transeúntes}

Semáforo en rojo.

Un mimo espera para cruzar.

La lluvia le ha desnudado parte del rostro.

Por mi piel sin maquillaje solo se desliza el agua.

Semáforo en verde.

No cruza. Permanece allá, inmóvil.

No cruzo. Me quedo aquí, de otro lado, mirándolo.

Me palpo la cara y miro la mano, como si quisiera comprobar que en mí también se ha borrado al menos una de mis máscaras.

\section{IMITACIón}

Solo transitamos un mimo callejero y yo.

No me imita, apenas me mira.

Tal vez ya se agotaron sus gestos para representar al otro.

A lo mejor imita mi inexpresividad y es mío su gesto lánguido.

Compartimos parte del trayecto.

Cercanos. Ajenos.

Como si ambos imitáramos la soledad. LPyH

Bibiana Bernal (Calarcá, 1985) es poeta, narradora y editora. Su poesía se ha traducido al griego, portugués y rumano. Dirige Cuadernos Negros Editorial y Fundación Pundarika. Premio de Poesía Comfenalco, de Gobernación del Quindío y finalista del Premio Nacional de Poesía Mincultura. 